\title{
Gambaran histopatologi penyembuhkan luka pencabutan gigi pada makrofag dan neovaskular dengan pemberian getah batang pisang ambon
}

\author{
Hendrik Setia Budi, Pratiwi Soesilowati, Zhafirah Imanina \\ Departemen Biologi Oral, Fakultas Kedokteran Gigi, Universitas Airlangga, Surabaya, Jawa Timur, Indonesia \\ JI Prof. Dr. Moestopo 47 Surabaya, Jawa Timur, Indonesia; e-mail: hendrik-s-b@fkg.unair.ac.id
}

Submisi: 28 Desember 2016; Penerimaan: 9 Januari 2017; Publikasi online: 29 Desember 2017

\begin{abstract}
ABSTRAK
Pembekuan darah sangat penting pada proses awal penyembuhan luka. Bekuan darah akan segera diisi oleh jaringan granulasi yang berasal dari induksi faktor pertumbuhan. Ekspresi platelet derived growth factors (PDGF)-BB yang diinduksi oleh pemberian gel ekstrak getah batang pisang ambon (Musa paradisiaca var. sapientum) dapat menunjukkan terjadinya peningkatan proliferasi fibroblas. Makrofag dan neovaskular sangat menunjang fase awal penyembuhan. Tujuan penelitian ini untuk membuktikan bahwa pemberian gel ekstrak getah batang pisang ambon (GEGPA) dapat meningkatkan jumlah makrofag dan neovaskular pada penyembuhan luka soket. Tikus strain Wistar sebanyak 36 ekor digunakan pada penelitian ini yang terbagi menjadi 3 kelompok. Semua tikus dilakukan pencabutan gigi pada insisive kiri mandibula. Kelompok pertama sebagai kontrol, pada soket diberi gel hidroksipropil metil selulosa (HPMC) 4\%, kelompok kedua diberi GEGPA $60 \%$, dan kelompok ketiga diberi gelatin sponge. Tikus dikorbankan pada hari ke-3 dan 5 untuk pemeriksaan histopatologi neovaskular dan makrofag pada soket. Hasil penelitian menunjukkan terdapat perbedaan yang bermakna terhadap kelompok kontrol pada jumlah neovaskular dan makrofag soket pada hari ke-3 $(p<0,05)$. Tidak ditemukan perbedaan yang bermakna pada jumlah neovaskular dan makrofag hari ke-5 ( $>>0,05)$. Disimpulkan bahwa pemberian GEGPA 60\% dapat mempercepat penyembukan luka pencabutan gigi melalui peningkatan jumlah makrofag dan neovaskular.
\end{abstract}

Kata kunci: getah batang pisang ambon; histopatologi; makrofag; neovaskular; soket

\begin{abstract}
Tooth extraction healing on macrophages and neovascular histopathology induced by ambonese banana stem sap gel. Blood clotting is very important in the early wound healing process. Blood clots will soon be filled with a connective tissue due to the induction of growth factors as granulation tissue. The expression of platelet derived growth factors (PDGF)-BB using the Ambonese banana stem sap gel (Musa paradisiaca var. sapientum) can increase the proliferation of fibroblasts. Macrophages and neovascular support in the early phase of healing. The purpose of this research was to demonstrate that Ambonese banana stem sap gel (GEGPA) can improve the macrophages and neovascular in the socket wound healing. Thirty six wistar rats were used and divided into 3 groups. The mandibular left incisor was extracted. The first group as control was given HPMC $4 \%$ gel on socket, the second group was given GEGPA $60 \%$, and third group was given gelatin sponge. Rats were sacrificed on day 3 and 5 for histopathology examination of neovaskular and macrophages on the socket. The results showed that there was significantly different in the control group on a number of neovascular and macrophages in socket on day $3(p<0.05)$. No significant difference on day 5 in all groups of neovascular and macrophages number ( $p>0.05$ ). It was concluded that the use of GEGPA $60 \%$ accelerated the wound healing of tooth extraction socket by means of macrophages and neovascular increasing.
\end{abstract}

Keywords: ambonese banana stem sap; histopathology; macrophage; neovascular; socket

\section{PENDAHULUAN}

Penyembuhan luka secara normal tampak sangat komplek, dengan melibatkan sel radang dan faktorfaktor pertumbuhan yang saling mempengaruhi pada setiap fase penyembuhan. Pembekuan darah yang terdiri dari fibronektin dan fibrin, merupakan tahap awal yang sangat menentukan dalam proses penyembuhan luka yang terjadi dalam hitungan menit hingga beberapa jam fase inflamasi akan didominasi oleh neutrofil dalam waktu beberapa jam hingga beberapa hari untuk mengeliminasi etiologi infeksi. Neutrofil kemudian digantikan oleh makrofag sebagai bagian dari fase inflamasi akhir pada 48 - 72 jam setelah terjadi luka untuk melanjutkan proses fagositosis. Proses diikuti fase proliferasi sel dan pembentukan pembuluh darah baru yang dikenal dengan jaringan granulasi. Tahap selanjutnya jaringan granulasi akan diremodeling dengan cara diganti oleh jaringan ikat yang didominasi oleh fibroblast. ${ }^{1,2}$ Jaringan sekitar luka yang didominasi 
oleh sel-sel radang seperti neutrofil dan makrofag dalam jangka waktu cukup lama penyebabkan pembentukan jaringan ikat akan terhambat. ${ }^{3}$

Fase proliferasi dimulai pada hari ke-3 sesudah terjadinya jejas, ditandai dengan terbentuk jaringan granulasi terdiri dari pembuluh darah baru (neovaskular), fibroblas, dan makrofag. Selanjutnya pada fase pembentukan jaringan, epitelisasi dan jaringan granulasi akan mengisi dan menutupi daerah luka guna memperbaiki kepadatan dan kerapatan jaringan. Proses sintesis, remodelling, dan infiltrasi struktural dari molekul matriks ekstraselular sangat ditentukan pada tahap awal dan lanjut dari penyembuhan luka. ${ }^{4}$ Studi terbaru menunjukkan bahwa makrofag dapat dijumpai pada beberapa tahap penyembuhan luka yang berbeda dan berpengaruh secara bervariasi terhadap setiap tahap perbaikan. Makrofag berperan untuk penyembuhan, namun dapat menyebabkan peradangan yang berlebihan atau fibrosis dalam jumlah yang tidak terkontrol. Disfungsi makrofag atau jumlah makrofag yang rendah dalam proses perbaikan jaringan menyebabkan penyembuhan luka tidak optimal, terhambatnya proliferasi fibroblas dan angiogenesis. ${ }^{5}$

Neovaskularisasi merupakan proses pembentukan pembuluh darah baru berupa tunastunas yang terbentuk dari pembuluh darah dan akan berkembang menjadi percabangan baru pada jaringan luka. Neovaskularisasi akan saling beranastomosis dan membentuk suatu jaringan sirkulasi darah yang padat pada jaringan luka. Pembuluh darah memiliki peranan penting dalam perbaikan jaringan untuk memberikan asupan nutrisi bagi jaringan yang sedang beregenerasi. Empat hal penting dalam regenerasi pada penyembuhan luka adalah kecukupan sel, pembuluh darah, faktor pertumbuhan dan scaffold. ${ }^{6}$

Penggunaan obat tradisional sekarang telah berkembang ke arah fitofarmaka, sehingga obat tradisional menjadi terstandar. Pisang ambon (Musa paradisiaca var.sapientum), merupakan tanaman yang banyak ditemukan di Indonesia, terutama di daerah yang banyak mendapat sinar matahari. Bagian tanaman pisang yang dapat dimanfaatkan sebagai obat adalah buah, kulit, batang dan getah. ${ }^{7}$ Pisang mengandung lektin dengan konsentrasi tinggi, dapat digunakan untuk penyembuhan luka melalui proses koagulasi atau pembentukan bekuan darah. ${ }^{8}$ Pemberian getah pisang terkandung lektin dapat mengaktifkan Glykoprotein-Ib (GP-lb) endotel yang berperan dalam perlekatan platelet. Aktivasi pada platelet menyebabkan pelepasan isi granula berupa faktor pertumbuhan seperti Platelet-derived growth factor (PDGF-BB) dan Transforming growth factor (TGF- $\beta 1) .{ }^{9}$

Pemberian secara topikal ekstrak getah batang pisang ambon (GEGPA) konsentrasi 30 dan $60 \mathrm{mg}$ dengan pelarut $4 \%$ hidroksipropil metil selulosa (HPMC)padadaerahsoket, menunjukkan peningkatan ekspresi PDGF-BB lebih cepat dibandingkan kontrol, sehingga proses penyembuhan luka semakin cepat. ${ }^{9}$ Telah dilakukan uji biokompatibilitas yang menunjukkan bahwa gel ekstrak getah batang pisang ambon (GEGPA) hingga konsentrasi 100\% relative tidak toksik terhadap sel fibroblas, dan mempunyai khasiat sebagai antiinflamasi dan analgesik. ${ }^{10}$ Namun demikian perlu dilakukan pembuktian bagaimana gambaran makrofag dan pembuluh darah baru pada penyembuhan soket dengan pemberian GEGPA secara ilmiah untuk mendukung penggunaan tanaman yang berkhasiat sebagai obat.

\section{METODE PENELITIAN}

Penelitian ini menggunakan metode eksperimental laboratoris, yang dilaksanakan pada bulan Juni-September 2016, di laboratorium Farmakologi Fakultas Kedokteran Universitas Airlangga setelah uji laik etik no.144/KKEPK.FKG/VII/2016. Hewan coba yang digunakan adalah tikus putih (rattus novergicus) strain Wistar jantan sebanyak 36 ekor usia 2-3 bulan, terbagi menjadi 3 kelompok. Kelompok 1 merupakan kelompok kontrol negatif dengan pemberian HPMC 4\% pada soket. Kelompok 2, yaitu kelompok dengan pemberian GEGPA, dan kelompok 3 yaitu kelompok kontrol positif dengan pemberian gelatin sponge (Spongostan $®$ ). Sampel dipilih secara randomized the post test only control group design.

Hewan coba dianestesi sesuai dengan berat badan ( $30 \mathrm{mg} / \mathrm{kg}$ thionembutal). Setelah teranestesi dibuat luka dengan melakukan tindakan pencabutan gigi insisive kiri mandibula. Paska cabut luka 
diberi bahan perlakuan sesuai kelompok ke dalam soket hingga penuh. Luka ditutup dengan cara dijahit menggunakan 5-0 vicryl (Ethicon; Johnson \& Johnson do Brasil, São Jose dos Campos, SP, Brazil). Dekapitasi dilakukan pada hari ke-3 dan 5, kemudian fiksasi jaringan menggunakan formalin $4 \%$ selama 24 jam, dekalsifikasi dengan $10 \%$ asam formik, dan pembuatan blok parafin. Pembuatan preparat dengan mikrotom ketebalan $6 \mu$ untuk pemeriksaan histologi makrofag dan neovaskular pada soket dengan pembesaran $400 x$ pada 10 lapang pandang yang berbeda.

Data jumlah makrofag dan neovaskular hari ke-3 dan 5 ditabulasi, kemudian data dianalisis dengan menggunakan uji one way anova dengan taraf kepercayaan 95\% mempergunakan bantuan software SPPS statistics 17.0. Uji statistik dilanjutkan dengan uji Least Significance Difference $(L S D)$ untuk membedakan antar kelompok.

\section{HASIL PENELITIAN}

Hasil pemeriksan histopatalogi anatomi (HPA) menggunakan mikroskop cahaya pembesaran 400x pada penyembuhan soket gigi tikus hari ke-3 dan 5 menunjukkan perbedaan gambaran jumlah makrofag (Gambar 1).
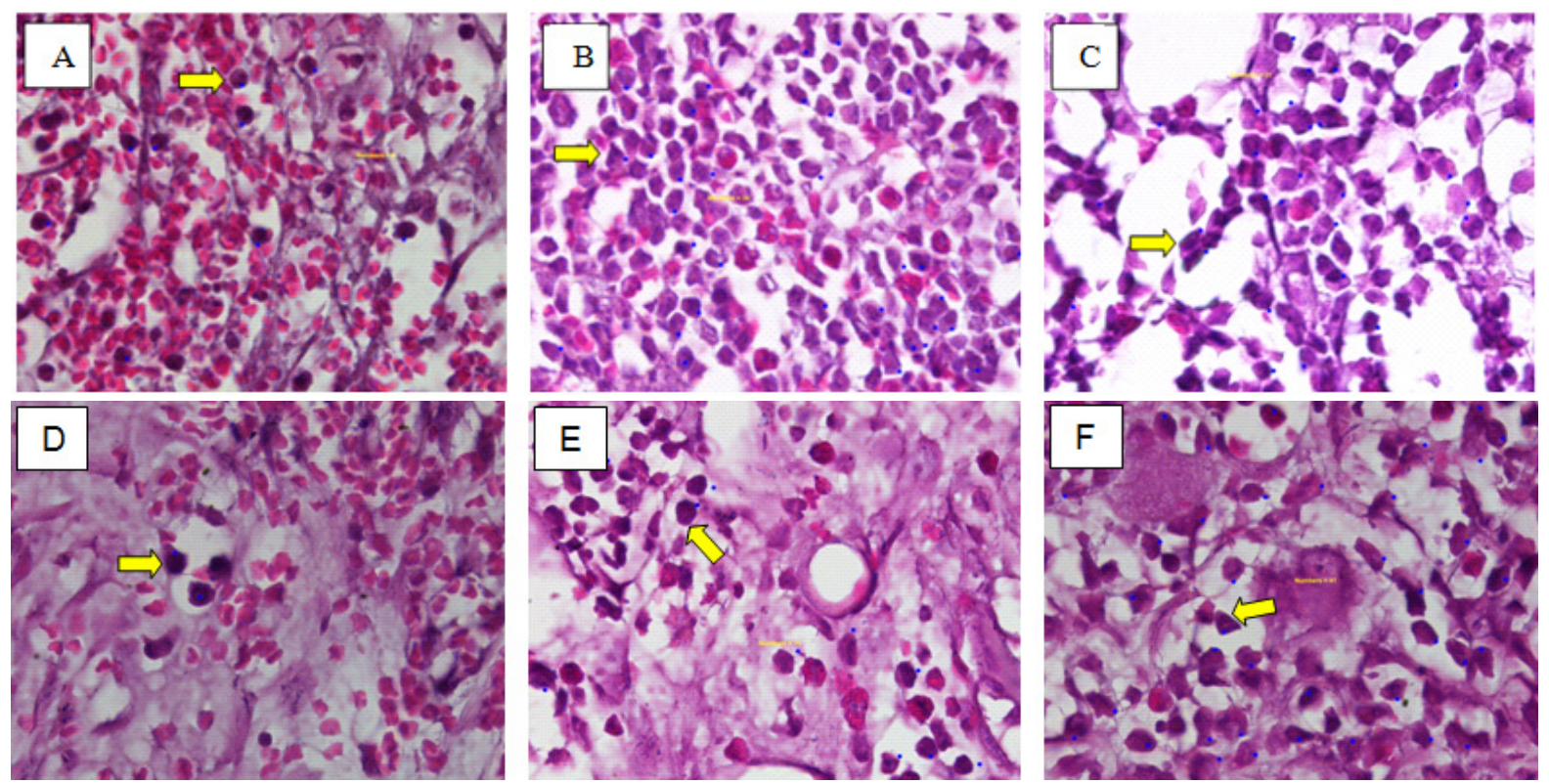

Gambar 1. HPA makrofag penyembuhan soket hari ke-3 dan 5

Keterangan: (A) kelompok HPMC 4\% hari ke-3; (B) kelompok GEGPA 60\% hari ke-3; (C) kelompok gelatin sponge hari ke-3, (D) kelompok HPMC 4\% hari ke-5; (E) kelompok GEGPA 60\% hari ke-5; (F) kelompok gelatin sponge. Pembesaran 400x. Tanda $\checkmark$ kuning menunjukkan makrofag. 
Majalah Kedokteran Gigi Indonesia. Desember 2017; 3(3): 121 - 127

ISSN 2460-0164 (print)

ISSN 2442-2576 (online)

Tabel 1. Rerata jumlah makrofag pada penyembuhan soket hari ke-3 dan 5

\begin{tabular}{|c|c|c|c|c|}
\hline & $\begin{array}{l}\text { HPMC } 4 \% \\
\bar{X} \pm S D\end{array}$ & $\begin{array}{l}\text { GEGPA } \\
\bar{X} \pm S D\end{array}$ & $\begin{array}{c}\text { Gelatin sponge } \\
\bar{X} \pm S D\end{array}$ & $\begin{array}{c}\text { Signifikansi } \\
p\end{array}$ \\
\hline Makrofag H-3 & $39,9 \pm 18,3^{a}$ & $94,1 \pm 33,9^{b}$ & $82,7 \pm 38,0^{a b}$ & 0,021 \\
\hline Makrofag H-5 & $28,2 \pm 18,1^{a}$ & $79,3 \pm 26,8^{b}$ & $53,5 \pm 35,6^{a b}$ & 0,020 \\
\hline
\end{tabular}

Keterangan: perbedaan superscipt menunjukkan perbedaan yang bermakna.
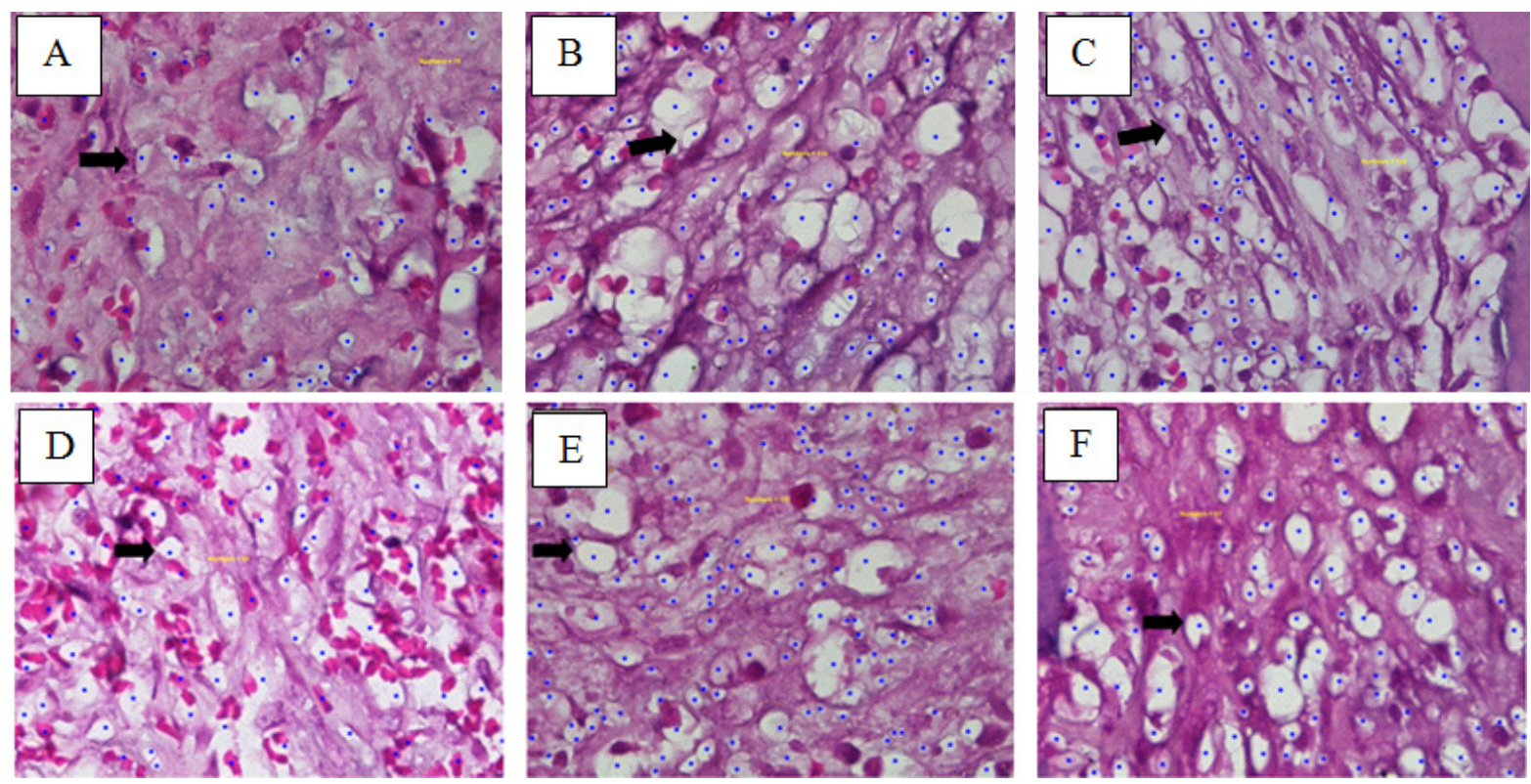

Gambar 2. HPA neovaskular penyembuhan soket hari ke-3 dan 5.

Keterangan: (A) kelompok HPMC 4\% hari ke-3; (B) kelompok GEGPA 60\% hari ke-3; (C) kelompok gelatin sponge hari ke-3, (D) kelompok HPMC 4\% hari ke-5; (E) kelompok GEGPA 60\% hari ke-5; (F) kelompok gelatin sponge. Pembesaran 400x. Tanda $\mathbf{T}$ hitam menunjukkan neovaskular.

Tabel 2. Rerata jumlah neovaskular pada penyembuhan soket hari ke-3 dan 5

\begin{tabular}{lcccc}
\hline & HPMC 4\% & GEGPA & Gelatin sponge & Signifikansi \\
& $\bar{X} \pm S D$ & $\bar{X} \pm S D$ & $\bar{X} \pm S D$ & $p$ \\
\hline Neovaskular H-3 & $57,6 \pm 10,9^{\mathrm{a}}$ & $93,7 \pm 24^{\mathrm{b}}$ & $68,7 \pm 13,6^{\mathrm{ab}}$ & 0,007 \\
Neovaskular H-5 & $82,7 \pm 12,0^{\mathrm{a}}$ & $79,6 \pm 14,8^{\mathrm{a}}$ & $70,6 \pm 7,2^{\mathrm{a}}$ & 0,217 \\
\hline
\end{tabular}

Keterangan: perbedaan superscipt menunjukkan perbedaan yang bermakna

\section{PEMBAHASAN}

Kelompok yang diberi GEGPA menunjukkan jumlah makrofag dan neovaskular yang tinggi dibandingkan kelompok lain. Hal tersebut menunjukan bahwa pemberian GEGPA yang mengandung beberapa senyawa poten seperti lektin dapat dengan mudah berikatan dengan (GP-lb), kemudian dapat menginisiasi peningkatan jumlah platelet sehingga segera terbentuk bekuan darah. Bekuan darah yang terbentuk kemudian akan diisi oleh fibrin dan faktor-faktor pertumbuhan seperti salah satunya adalah PDGF-BB. ${ }^{10}$
Tingginya jumlah makrofag pada hari ke 3 dan 5 kelompok GEGPA dibandingkan kelompok lain menunjukkan bahwa GEGPA dapat menginduksi makrofag di sekitar luka. Makrofag banyak berperan pada proses fagositosis sebagai proses imunologi non-spesifik terhadap antigen. Sesuai dengan penelitian sebelumnya, bahwa saponin dan lektin pada gatah batang pisang memodulasi respon imun dengan peningkatan limfosit sel $\mathrm{T}$ dengan penanda $\mathrm{CD}^{+}, \mathrm{CD}^{+}$and $\mathrm{CD}^{+}$dan sistem hematopoetik, sehingga dapat meminimalisir terjadinya infeksi. ${ }^{11}$ Peran sel T adalah sebagai aktivator limfosit sel B, 
sel NK dan makrofag ketika mendapatkan paparan antigen. ${ }^{12}$ Kelompok kontrol menunjukkan jumlah makrofag paling rendah dibandingkan kelompok lain karena HMPC merupakan bahan pembuat gel yang tidak menyebabkan hambatan pada penyembuhan di daerah sekitar luka. Gelatin sponge merupakan bahan absorban yang membantu dalam kontrol perdarahan, sehingga mempercepat terbentuknya bekuan darah dan sekitar luka dapat segera terisi oleh proliferasi jaringan.

Makrofag merupakan unsur sel yang penting pada pembentukan jaringan granulasi. Selain membersihkan debris ekstraseluler dan fibrin pada tempat jejas, makrofag juga menginduksi proliferasi fibroblas dan produksi matriks ekstraseluler pada hari ke-2. Penurunan jumlah makrofag pada hari ke-5 menunjukkan bahwa proses inflamasi telah banyak berkurang, dan luka akan diisi oleh proliferasi jaringan. Namun demikian tingginya jumlah makrofag disertai dengan tingginya rerata nilai deviasi. Hal tersebut dapat disebabkan oleh pengaruh perbedaan besarnya trauma pada proses pencabutan gigi tikus sehingga respon dalam menginisiasi sel-sel yang berperan pada proses penyembuhan cukup bervariasi.

Guide Bone Regeneration (GBR) merupakan standar pengobatan rutin untuk regenerasi alveolar bone. Konsep dasar yang mendasari GBR adalah untuk mengecualikan jenis sel tertentu pada daerah regeneratif, kemudian meningkatkan adanya sel spesifik lain melalui respon angiogenik..$^{13}$ Tindakan pencabutan gigi akan menyebabkan keradangan dan perdarahan di sekitar daerah luka. Tubuh mempunyai kemampuan untuk merespon injuri dengan membentuk sumbat platelet di daerah luka. Apabila terjadi gangguan pembekuan darah, maka akan menyebabkan terlambatnya penyembuhan luka dan memungkinkan terjadinya infeksi. ${ }^{14}$

Aktivitas GP-lb endotel berperan dalam perlekatan platelet ke daerah luka, sehingga mengaktivasi platelet untuk segera melepaskan isi granula berupa faktor pertumbuhan seperti PDGFBB dan TGF- $\beta 1$. Platelet yang telah teraktivasi akan menyebabkan platelet lain untuk beragregrasi dan segera memenuhi daerah luka membentuk sumbat platelet primer dan bekuan darah yang stabil pada daerah luka. Pembentukan bekuan darah pada daerah luka, akan segera diisi oleh sel mesenkim, fibroblas, osteoblas dan kondroblas yang bermigrasi, kemudian berproliferasi dan berdiferensiasi akibat pengaruh PDGF-BB. Sebagai kemotaktik kuat, PDGF-BB akan menarik makrofag untuk fagositosis bahan asing atau mikroba pada saat terjadinya luka. ${ }^{10,13,15}$

Penggunaan gelatin sponge dapat mempercepat terbentuknya bekuan darah, namun dalam penelitian ini menunjukkan sedikit peningkatan jumlah makrofag. Hal tersebut membuktikan bahwa bahan material tersebut tidak dapat diserap secara sempurna sehingga pada luka tidak banyak diisi oleh sel-sel radang yang banyak berperan dalam proses penyembuhan. Hal tersebut sesuai dengan penelitian lain yang menunjukkan bahwa pemberian gelatin sponge hingga hari ke-28 masih meninggalkan material yang dapat menyebabkan terlambatnya proses penyembuhan luka. ${ }^{16}$

PDGF-BB akan teraktivasi setelah berikatan dengan reseptornya pada PDGFR- $\alpha$ dan $\beta$, selanjutnya menyebabkan signaling sel melalui fosforilasi Ras, Raf dan MAPK. PDGF-BB pada fibroblas dan kondroblas, menyebabkan kemotaktik, mitotik dan mensintesis kolagen, sedangkan pada osteoblas di daerah luka akan menstimulasi proliferasi dan sekresi faktor pertumbuhan seperti BMP sebagai faktor yang berpengaruh pada pembentukan matriks ekstraseluler tulang. BMP akan mengatur signal transduksi melalui reseptor serine-threonine kinase tipe I dan II. Reseptor protein kinase tersebut akan memfosforilasi signaling intraseluler SMAD dan masuk ke dalam nukleus untuk memproduksi protein matrik ekstraseluler dan merangsang diferensiasi sebagai proses pembentukan tulang baru. ${ }^{17,18}$

Bekuan darah yang stabil pada proses penyembuhan luka, akan segera diinfiltrasi oleh faktor-faktor pertumbuhan seperti PDGF, TGF- $\beta 1$ dan VEGF untuk segera memperbaiki jaringan yang rusak. PDGF-BB merupakan subtipe PDGF yang mempunyai peran besar pada awal penyembuhan luka dengan menarik sel makrofag, mesenkim, fibroblas dan osteoblas untuk mendekat pada 
daerah luka, sedangkan VEGF dan FGF-2 berperan sebagai kemotaktik neutrofil dan pembentukan pembuluh darah yang baru. ${ }^{19}$ Peningkatan jumlah neovaskular yang lebih cepat pada kelompok yang diberi GEGPA dibandingkan kontrol dan gelatin sponge menggambarkan bahwa pemberian GEGPA dapat mempercepat penyembuhan luka melalui pembentukan pembuluh darah baru, sehingga dapat membawa komponen molekuler penyembuhan lainnya untuk mengisi jaringan luka dengan jaringan yang baru.

Beberapa penelitian telah mengungkap proses penyembuhan luka dengan menambahkan penggunaan faktor pertumbuhan yang tersedia secara komersial seperti PDGF, yang dapat dikombinasi dengan prosedur material cangkok tulang untuk peningkatan regenerasi tulang. ${ }^{13,20,21}$ PDGF berperan terutama melalui kemotaksis dan proliferasi, hal tersebut ditunjukkan dengan peningkatan angiogenesis. ${ }^{22,23}$

\section{KESIMPULAN}

Kesimpulan dari penelitian ini adalah bahwa pemberian GEGPA 60\% dapat mempercepat penyembuhan luka pencabutan gigi melalui peningkatan jumlah makrofag dan neovaskular. Perlu dilakukan penelitian lanjut mengenai daya sebar dan pelepasan sediaan obat untuk menunjang efektifitas dan stabilitas.

\section{UCAPAN TERIMA KASIH}

Ucapan terima kasih kami sampaikan kepada Rektor Universitas Airlangga yang telah membantu dalam pendanaan penelitian ini melalui RKAT Fakultas Kedokteran Gigi Universitas Airlangga.

\section{DAFTAR PUSTAKA}

1. McLennan SV, Bonner J, Milne. Matrix metalloproteinases and their roles in poor wound healing in diabetes. Wound Prac Res. 2008; 16(3): 116 - 121.

2. Velnar T, Bailey T, Smrkolj V. The wound healing process: an overview of the cellular and molecular mechanisms. J Int Med Res. 2009; 37(5): 1531 - 1534.

3. Falanga V. Wound healing and its impairment in the diabetic foot. Lancet 2005; 366: 1736 - 1743.

4. Brancato SK, Albina JE. Wound macrophages as key regulators of repair origin, phenotype, and function. Am J Pathol. 2011; 178(1): $19-25$.

5. Koh TJ, DiPietro LA. Inflammation and wound healing: the role of the macrophage. Expert Rev Mol Med. 2011; 11(13): e23. doi: $10.1017 /$ S1462399411001943.

6. Reinke JM, Sorg H. Wound repair and regeneration. Eur Surg Res. 2012; 49: $35-43$.

7. OGTR. The biologi of musa. Document Prepared by the Office of the Gene Technolgy Regulator. Vol 1. Canberra. Australia. 2008 (cited2008 November 11). Available online on http://www.ogtr.gov.au.

8. Coopoosamy RM. In-vitro studies on lectin derivatives of aloe excelsa (Berger). J Med Plants Res. 2010; 4(17): 1738 - 1742.

9. Budi HS, Kriswandini IL, Sudjarwo SA. Ambonese banana stem sap (Musa paradisiaca var. sapientum) effect on PDGF$\mathrm{BB}$ expressions and fibroblast proliferation in socket wound healing. Int J ChemTech. 2016; 9(12): 87 - 95.

10. Budi HS, Arundina I, Indrawati R, Mahardikasari L. Uji toksisitas akut ekstrak batang pisang ambon (Musa paradisiacavar sapientum) terhadap hati mencit (Mus musculus) dengan parameter LD (Acute toxicity test of ambonese banana (Musa paradisiaca var sapientum) stem extract in liver of mice (Mus musculus) with LD 50 parameters 50 . Journal of Dentomaxillofacial Science. 2014; 13(2): 86 - 90. DOI:10.15562/jdmfs.v13i2.394.

11. Swanson MD. Molecular engineering of a banana lectin that inhibits hiv-1 replication. The University of Michigan, Dissertation; 2010. 16. 
12. Iqbal RZ, Song-hua H, Chen-wen X, Arijo AG. Adjuvant effects of saponins on animal immune responses. J Zhejiang Univ Sci. 2007; 8(3): $153-161$.

13. Kaigler D, Silva EA, Mooney DJ. Guided bone regeneration (GBR) utilizing injectable vascular endothelial growth factor (VEGF) delivery gel. J Periodontol. 2012. DOI: 10.1902/jop.2012.110684.

14. Basi DL, Hughes PJ, ThumbigereMath V, Sabino M, Lunos SA, Jensen E, Gopalakrishnan R. Matrix metalloproteinase-9 expression in alveolar socket of zoledronic acid-treated rats. J. Oral Maxillofac Surg. 2011; 69(11): 2698 - 2707

15. Simion M, Rocchietta I, Kim D, Nevins M, Fiorellini J. Vertical ridge augmentation by means of deproteinized bovine bone block and recombinant human platelet-derived growth factor-BB: a histologic study in a dog model. Int J Periodontics Restorative Dent. 2006; 26: $415-423$.

16. Bum SK, Young CN, Young WJ. Comparison of the wound healing effect of cellulose and gelatin: An in vivo study. Arch Plast Surg. 2012; 39(4): 317 - 321.

17. Garrant PR. Oral cells and tissues. New York: Quintessence Publishing, Stony Brook; 2003. $195-219$.
18. Zhang YD, Chen Z, Song YQ, Liu C, Chen YP. Making a tooth: Growth factors, transcription factors, and stem cells. Cell Research. 2005; 15(5): $301-316$.

19. Fiedler J, Roderer G, Gunther KP, Brenner RE. BMP-2, BMP-4 and PDGF-BB stimulate chemotactic migration of primary human mesenchymal progenitor cells. Journal of Cell Biochemistry. 2002; 87: $305-312$.

20. Schwarz F, Ferrari D, Sager M, Herten M, Hartig B, Becker J. Guided bone regeneration using rhGDF-5- and rhBMP-2-coated natural bone mineral in rat calvarial defects. Clin Oral Implants Res. 2009; 20: 1219 - 1230.

21. Stephan EB, Renjen R, Lynch SE, Dziak R. Platelet-derived growth factor enhancement of a mineral-collagen bone substitute. J Periodontol. 2000; 71: 1887 - 1892.

22. Nevins M, Giannobile WV, McGuire MK, Kao RT, Mellonig JT, Hinrichs JE, McAllister BS, Murphy KS, McClain PK. Platelet-derived growth factor stimulates bone fill and rate of attachment level gain: results of a large multicenter randomized controlled trial. J Periodontol. 2005; 76: 2205 - 2215.

23. Camelo M, Nevins ML, Schenk RK, Lynch SE, Nevins M. Periodontal regeneration in human Class II furcations using purified recombinant human platelet-derived growth factor-BB (rhPDGF-BB) with bone allograft. Int J Periodontics Restorative Dent. 2003; 23: $213-225$. 